Scientia Militaria vol 40, no 3, 2012, pp.472-500. doi: 10.5787/40-3-1037

\title{
Considerations on Defence Thinking in Post-1994 South Africa with Special Reference to Post-conflict Reconstruction and Development
}

\author{
Theo Neethling •
}

\begin{abstract}
This article revisits some of the main arguments presented (in the South African context) since the late 1990s in relation to the regional security demands placed on the South African National Defence Force (SANDF) on the one hand, and the configuration of the force design imposed on the SANDF on the other. These issues are of great relevance to the South African Department of Defence's recent (2012) official pronouncements and related defence thinking on the current and future external role of the South African military, specifically with regard to post-conflict reconstruction and development. The aim of the article is to examine the dynamics of recent years - philosophical and practical - that gave rise to the policy "move" or "shift" from defence in a democracy (1998) to defence, security and development (2012). ${ }^{1}$ In addition, the article aims to analyse and discuss the new comprehensive guidelines for defence force design in the Draft Defence Review 2012 and reflects on some of the most important policy implications for the SANDF in this regard - specifically given the demands placed on the SANDF in the field of post-conflict reconstruction and development. The author contends that the Department of Defence has now gained a clearer idea or perspective of what the future role(s) of the South African military should be through the assessment of its function, principles and goals expounded in the Draft Defence Review 2012.
\end{abstract}

Professor and Head of the Department of Political Studies and Governance at the University of the Free State. 
Keywords: Post-conflict reconstruction and development, Defence Review, defence thinking, peace missions, South African National Defence Force, defence capabilities

\section{Introduction}

The South African Constitution, the 1996 White Paper on Defence and the subsequent Defence Review 1998 are all unambiguous in defining the primary function of the SANDF as that of defending and protecting the South African state, its territorial integrity and its people. Generally, this boils down to defence against external military aggression or threats. Although the above-mentioned policy stance is logical and or straightforward, its practical consequences have been severely criticised for many years. Firstly, the focus on external aggression has resulted in a concentration of defence spending on conventional military capabilities. This has resulted in institutional tension between what is conceptually needed and practically attainable within the defence domain specifically concerning the budgetary importance attached to the so-called primary function of the SANDF, namely securing territorial integrity on the one hand, and the execution of its priority tasks in a politico-diplomatic context (specifically peace missions) on the other.

More than fifteen years have passed since the original drafting of the Defence Review 1998. Ongoing political dynamics in Southern Africa, on the broader African continent and among the international community at large have changed the external foreign policy and security environment. As Mills ${ }^{2}$ rightly argues, "[a]dapting to those changes and re-designing for the future means reorienting the defence force as an African peace-builder, enabler primus inter pares."

Following the many critical comments and reflections on the Defence Review 1998 since the issuing of this document, at least two matters should be considered: firstly, the strategic environment and politico-diplomatic expectations of government, and secondly, the funds that are available to meet those expectations. The question is how these two variables or drivers can be aligned, because any force design should invariably be budgetdriven. Furthermore, any Defence Review worthy of the name should examine three key issues: The strategic environment: What will threats look 
like over the next twenty years? Capabilities: Current and projected? Affordability: What can the country afford - in financial and workforce terms, not just to buy, but also to operate? ${ }^{3}$

On 4 May 2010, the Minister of Defence and Military Veterans, Lindiwe Sisulu, delivered her budget speech in Parliament. During this speech, she remarked as follows on the need to develop an updated and future defence policy framework: ${ }^{4}$

Major changes, both dramatic and evolutionary, have taken place in the defence environment over the past 15 years. The policy review and strategy would of necessity take this in consideration and will be informed by a cleareyed assessment of what we want our foreign policy to achieve, the potential threats facing us, and socio-economic interests in what is a very uncertain era of growing competition among new major powers. The new environment requires new thinking and new approaches ...

For the SANDF and particular the SA Army to remain successful, it will have to take into account the complexities of African politics. The size of the continent, its geographic and climate complexity, as well as the lack of transport infrastructure, problems engendered by economic under-development and the diverse military challenges it may encounter, will necessitate the SANDF to be well and appropriately equipped and trained for both its external and internal roles as prescribed by the Constitution.

The Draft Defence Review $2012^{5}$ makes it clear that Africa is at the centre of South Africa's foreign policy, and that South Africa must continue to support regional and continental processes to respond and resolve crises. The country should also strengthen regional integration, increase interAfrican trade and development, and importantly, champion sustainable development and related opportunities on the African continent. In addition, peace, stability and security are viewed as essential preconditions for development. South Africa, and this specifically involves the South African military, must consequently remain a leading role-player in conflict prevention, peace enforcement, peacekeeping, peacebuilding and even postconflict reconstruction. ${ }^{6}$ The latter is clearly linking South Africa's security role with a developmental role on the continent. It is also envisaged that the long-awaited African Standby Force (ASF) will be functional in 2015 and South Africa is likely to be one of the main role-players in the operational 
activities of the ASF, specifically to promote the international goal of security with development.

The Draft Defence Review 2012 states that the security sector in countries emerging from conflict is often seriously deficient. In this regard, security sector reform (SSR) is highlighted as an indispensable aspect of conflict resolution and the creation of sustainable security. The security sector of a country, comprising the armed forces, police, intelligence services, judiciary and prisons services, plays a key role in maintaining peace, stability and the rule of law. ${ }^{7}$ This being considered, it seems that the SANDF will have an active role to play in years to come regarding the notion of post-conflict reconstruction and development (PCRD) as developed by the African Union (AU) in recent years. The Draft Defence Review 2012 specifically states that developmental peacekeeping will "inevitably be executed" in a joint interdepartmental, interagency and multinational context. ${ }^{8}$ To achieve this, South Africa will have to "develop and maintain an appropriate, affordable and adequately balanced defence force". ${ }^{9}$

In view of the above, the aim of this article is to examine and explore the dynamics of recent years - philosophical and practical - that gave rise to the policy "move" or shift from defence in a democracy (1998) to defence, security and development (2012). In addition, the article aims to analyse and discuss the new comprehensive guidelines for defence force design in the Draft Defence Review 2012 and reflect on some of the most important policy implications for the SANDF in this regard. As part of this analysis, the focus will be placed on some of the main arguments presented (in the South African context) since the late 1990s in response to the demands placed on the SANDF on the one hand, and the configuration of the force design imposed on the SANDF on the other. These issues are undoubtedly important to understand South Africa's most recent official pronouncements and related defence thinking on the current and future external role of the South African military, specifically given the political-strategic demands placed on the SANDF in the field of PCRD. 


\section{Defence in a Democracy: Entrance into Peace Missions}

South Africa's negotiated transition to democracy during the 1990s brought about a new context in terms of military posture and engagement. Since 1994, the new South African government with former President Nelson Mandela as head of state wished to distance itself from the past of regional power politics and political-economic dominance over Southern Africa. Instead, the government wished to identify South Africa with the promotion of human rights, peace and development on the African continent. ${ }^{10}$ The new government therefore introduced a low-risk approach and policy that not only revived international diplomacy, but deliberately placed limitations on and reduced the use of the military instrument in South Africa's foreign policy. The Mbeki era (since 1999), however, brought about the reemergence of the military instrument in South Africa's foreign policy, linking direct national interests - often identified with the African continent - with broader foreign policy goals. ${ }^{11}$ In fact, it could be argued that the military was chosen to facilitate South Africa's foreign policy goals in Africa in view of its strength and capabilities.

In this context, the Defence Review 1998 stated that after two and a half decades of international isolation, South Africa was readmitted into the international community. The country's relations with its neighbouring states changed from suspicion and animosity to cooperation and friendship. The country has also joined a host of important regional and international institutions and engaged in defence cooperation with a number of countries and regional security arrangements. The authors of the Defence Review 1998 also anticipated that the SANDF would be required to participate in regional defence arrangements and engage in peace missions. They further indicated South Africa's common destiny with Southern African states and contended that peace and stability in South Africa could only be achieved in a context of regional stability and development. ${ }^{12}$

One of the major changes in patterns of diplomacy since the early 1990s has been the increasing use of military cooperation and assistance in the international community. These changes have not come about through the traditional roles of militaries as providers of defence capabilities, but rather as instruments for attempting to build cooperative relations and helping to prevent or resolve conflicts. ${ }^{13}$ This, of course, stands in stark 
contrast to situations where foreign ministries find themselves in a situation of structural rivalry with militaries, where militaries pursue sectional interest and are lacking in the cooperative capacity traditionally found in the diplomatic domain. ${ }^{14}$

Practically in the international arena, the establishment of the now defunct Multinational High Readiness Standby Brigade for United Nations Operations (SHIRBRIG) (1996-2009) is but one example of how defence diplomacy has manifested in contemporary world affairs. The envisioned Africa Standby Force (ASF) is a similar case in the African context. SHIRBRIG was premised on the idea of a rapid deployment force, consisting of military units from several member states, trained to the same standard, using the same operating procedures and inter-operable equipment, and regularly engaging in combined exercises. This move towards cooperation and interoperability was further reinforced by the Report of the Panel on United Nations Peace Operations in 2000, also known as the Brahimi Report, which called for coherent brigade-size forces from a group of nations that have been co-operating and developing common training and equipment standards, common doctrine, and common institutional arrangements. ${ }^{15}$

In the South African arena of defence diplomacy, Du Plessis ${ }^{16}$ points out that the military instrument has become more salient in South Africa's foreign policy, most notably in the form of peace missions of varying types in support of diplomatic initiatives to resolve conflict. Esterhuyse ${ }^{17}$ also states that, during the Mbeki era (1999-2008) - considering the importance of peace and security in South Africa's foreign policy outlook on the continent - the SANDF became a leading South African foreign policy instrument in Africa.

Having outlined its policy guidelines on participation in peace missions, government decided to involve the SANDF practically and operationally in United Nations (UN) peace missions in two African states. Towards the end of 2000, an announcement was made that a limited number of South African officers would be deployed as military liaison officers to support the internationally brokered peace process between Ethiopia and Eritrea, specifically to serve in the UN Mission in Ethiopia and Eritrea (UNMEE). Furthermore, in a significant announcement in March 2001, the 
South African government stated that, in compliance with the international obligations of South Africa towards the UN, the SANDF would contribute elements of specialised units to the UN Organisation Mission in the Democratic Republic of Congo (MONUC). This announcement was a historical development in that it paved the way for the SANDF's first substantial contribution, specifically of a human resources nature, to international peace missions.

These developments also coincided with the deployment of South African troops in Burundi in October and November 2001 with a view to protecting about 150 Burundian political leaders who returned from exile to participate in that country's power-sharing transitional government. In the early months of 2003, the number of South African troops deployed in the above-mentioned missions stood at about 900 SANDF servicemen and women. ${ }^{18}$ Since then, South Africa's contributions as a troop-contributing nation in international peace missions have expanded and grown considerably.

The "re-entrance" of the military into the foreign policy domain was strikingly articulated by the former chief of the SANDF, General Siphiwe Nyanda: ${ }^{19}$

South Africa has just recently become involved in peace missions in Africa, and more deployments are on the horizon. After a healthy pause, post-1994, during which time the SANDF integrated and transformed, the SANDF is on the march - a march for peace, development and prosperity.

Towards the end of the 2000s, South Africa, found itself in the league of those troop-contributing nations who were assigning substantial numbers (more than 1000 ) of uniformed personnel to UN peace missions. More specifically, South Africa found itself in the league of African countries such as Nigeria, Rwanda and Ghana Ethiopia, Egypt, Senegal and Morocco - all countries with considerable experience in the UN peacekeeping arena and all important troop-contributing nations to UN missions.

South Africa's involvement in international peace missions has always been viewed as a secondary function of the SANDF. The South African White Paper on Participation in International Peace Missions, on the basis of the Defence Review 1998, reiterated its position that the SANDF's 
participation in peace missions would be "at the level of up to one infantry battalion group". ${ }^{20}$ This policy position was soon overtaken by events in Burundi, the DRC and the former Sudan. The White Paper also alluded to the point that peace missions should be viewed as "long-term endeavours which include a significant investment in peace building and not merely as short-term engagements". ${ }^{21}$ Peacebuilding was defined as the inculcation of respect for human rights and political pluralism, the accommodation of diversity, building the capacity of state and civil institutions, and promoting economic growth and equity. ${ }^{22}$ The above-mentioned coincided with a strong scholarly emphasis on human security and a broadening of traditional concepts of security. South Africa, in fact, published a series of official documents - among the most comprehensive in the world - in its embrace of the notion of human security. ${ }^{23}$ In this context, the White Paper specifically stated that instability must provide for a focus on issues relating to effective governance, robust democracies and ongoing economic and social development. ${ }^{24}$ Yet, nothing specific or explicit was said or highlighted as far as practical implications or specific focus areas of military involvement (such as SSR as a focus area of peacebuilding) were concerned.

Generally, developments in South Africa coincided with a worldwide conviction that contemporary armed conflicts require sustained efforts that address not only the military dimensions of conflict, but also the political, humanitarian, economic and social dimensions of conflict. It is to this end that a range of reforms has been implemented throughout the international system to facilitate peacebuilding endeavours. By specifically expanding the traditional concept of peacekeeping beyond conventional military operations, several role-players in the international community started to give recognition to the potential that activities of a developmental nature can bring to address the deepest causes of conflict. ${ }^{25}$

An important development in the South African context relates to research conducted on what became known as developmental peacekeeping (DPMs). In brief, developmental peacekeeping has been developed since 2004 as a conceptual tool to work towards integrated efforts at both the strategic and operational levels to fill the institutional gap between military peacekeeping and development activities. The concept was formally introduced and presented to Parliament, based on several initiatives and research facilitated by a former South African Deputy-Minister of Defence, 
Ms Nozizwe Madlala-Routledge, in conjunction with members of the Council of Scientific and Industrial Research (CSIR). ${ }^{26}$

The concept of DPMs emphasises the notion that conflict prevention begins and ends with the promotion of human security and human development. It is aimed at directly addressing the causes of the many intrastate wars in Africa, not only by providing short-term peace and security, but by also by providing long-term solutions to the conflict and by establishing the foundations for sustainable peace and development. DPMs, with reference to conflicts in Africa, are aimed at bringing peacekeeping closer to development to lessen the recurrence of violence - a phenomenon so prevalent in Africa that peace missions seem to have a less than $50 \%$ chance of success. In fact, history has proved that in more than $60 \%$ of peace interventions, belligerents return to the use of violence within five years after the peacekeepers have left the country. DPMs as a conceptual tool therefore aims at providing a strategy for making a quick transition from the military's peacemaking and peacekeeping mission to the longerterm peacebuilding missions of intergovernmental and non-governmental organisations. ${ }^{27}$

The notion of DPMs is essentially based on the premise that engaging in development and reconstruction efforts as soon as possible - even when conflict is still ongoing - could contribute towards security, peace, and longterm political order and economic legitimacy. Fundamentally, DPMs as a concept calls for a developmental approach, which means embarking on these initiatives in unison with security efforts, as well as quicker mobilisation of reconstruction and development resources. "On an operational level this implies many things, among these, the deployment of civilian peace builders alongside military peacekeepers". ${ }^{28}$ DPMs as a concept has thus been presented as a theoretical and practical tool for effecting peacebuilding in strife-torn nations and, ultimately, to set the stage for sustainable security and development in a context where the risk of conflict has been reduced or minimised.

As far as the South African military is concerned, the Draft Defence Review 2012 pronounces - clearly on the basis of DPMs or at least coinciding with the concept - that the military will pursue reconstruction and conditions conducive to long-term peace and security building in 
support of peacekeeping objectives. This will be further explored in the section below.

\section{Defence, Security and Development: Generating New Challenges and Questions}

Like Brazil, South Africa has been called upon to assume important political responsibilities in the field of peace and stability, and both countries have operated far beyond their immediate neighbourhoods. Significantly, Brazilian leaders have acknowledged that they will not be able to take on a leadership role in the international community without "the associated costs" and spending on the military. Unlike South Africa, Brazil is one of the ten largest economies in the world and the country seems to be more willing than ever before to invest in its military. ${ }^{29}$ This being said, the question is: where does that leave South Africa in terms of its political leadership or powerful economic position in the larger African context?

Under the theme, defence, security and development, the Draft Defence Review 2012 points out that the changing political-strategic environment has generated new challenges and new opportunities for the SANDF. South Africa's political and economic integration into especially the AU has led to greater involvement on the continent and in continental affairs, not least of which has been an active role in the newly established regional and continental security architecture, including the establishment of the AU Peace and Security Council. ${ }^{30}$ Needless to say that given its strong economic and military position on the African continent, South Africa could not escape the AU's position in the search for security and peace on the continent. Even though South Africa's continental involvement is sometimes viewed as "gigantism", which is negatively associated with regional dominance and hegemonic intent, South Africa is certainly the leading, most advanced and sophisticated African economy. To this end, it is the one economy that can contribute substantially to the financial demands of peacekeeping and PCRD on the African continent.

For the AU, PCRD is one of the tools of the AU designed to curb the severity and repeated nature of conflicts in Africa as well as to bring about sustained development. In 2005, the AU Executive Council urged the AU Commission to develop an AU policy framework on PCRD based on the 
provisions of the AU Peace and Security Council Protocol and the experience gained in the African context. In June 2006, the Executive Council adopted the AU PCRD policy of which the explicit objective is to improve timelines, effectiveness and coordination of activities in postconflict countries, as well as to lay the foundation for social justice and sustainable peace. In accordance with the position of African leaders in general and the AU's vision of renewal and growth in particular, the PCRD policy is intended to serve as a tool for the development of comprehensive policies and strategies that seek to consolidate peace and prevent a relapse into violence. It also seeks to help address the root causes of conflict and encourage fast-track planning and implementation of reconstruction activities. Furthermore, it intends to enhance complementarities and coordination between and among diverse actors engaged in PCRD processes. The AU's PCRD policy also endeavours to complement the UN Peace Building Commission's work in identifying states that are at risk of becoming failed states by providing timely help to such states and peoples, and in that way contributing towards lowering the potential or rate at which war-torn countries may relapse into conflict. Again, this is based on the necessity of development work to address the deepest causes of conflict. The policy has six elements that are both self-standing and cross-cutting, and which represent the pillars upon which all PCRD efforts should be developed: ${ }^{31}$

- $\quad$ security;

- $\quad$ humanitarian/emergency assistance;

- $\quad$ political governance and transition;

- $\quad$ socio-economic reconstruction and development;

- $\quad$ human rights, justice and reconciliation; and

- $\quad$ women and gender.

On 14 September 2011, the AU issued a press release stating that the Commission of the AU deployed two technical support teams to Liberia and Sierra Leone - countries that are still recovering from conflict. It was also announced that missions would be undertaken to Sudan and the newly established (Republic of) South Sudan. In addition, the AU was preparing for an African Solidarity Initiative, which would be working towards financial contributions from member states as well as human resource 
contributions and capacity building. This implies active participation not only of member states, but also of non-state actors and relevant public enterprises. ${ }^{32}$

Internationally and specifically on the African continent, the following can be highlighted as the major challenges associated with PCRD at continental level: ${ }^{33}$

- Bringing together all of the relevant actors, including international donors, the international financial institutions, national governments, and troop-contributing countries;

- Marshalling resources; and

- Advising on and proposing integrated strategies for post-conflict peacebuilding and recovery and where appropriate, highlighting any gaps that threaten to undermine peace.

While economic and other challenges facing the continent will compel Africans to pursue outside assistance for a long time to come, observers remain convinced that South Africa has the potential to contribute significantly to peace and stability operations on the continent. Specifically, this involves the SANDF as a foreign policy instrument. Politically, it is expected of the SANDF to be ready for any regional or continental security challenge or occurrence that may threaten the safety and security of the country and its peoples, or even its neighbours. The SANDF must also be ready to meet the country's international commitments and it should be noted that South Africa remains one of the top 15 contributors to UN peace missions worldwide. ${ }^{34}$ In this regard, the role of the SANDF in postconflict Burundi, the DRC and the former Sudan has been internationally acknowledged and experiences gained will serve as a foundation for future involvement in peace missions on the African continent. Besides, South Africa is certainly endowed with the ability to make inputs on strategic thinking and to contribute ideas and knowledge on how to promote "security with development" on the African continent.

Earlier, the European Union's special advisor for African peacekeeping argued that the South African military is ideally placed to help train the African Union's Standby Force, which is still to be operationalised throughout the continent. General Pierre-Michel Joana stated that the 
SANDF can play an important role in helping the AU become self-sufficient in crisis management on the continent. "SA is probably the best Army, the best equipped forces in all Africa. They also have very important human resource in terms of beneficiation and capability of command," he said. ${ }^{35}$ This might seem to be a bit ambitious in terms of international expectations, but as already suggested, South Africa is the leading, most advanced and sophisticated African economy. The country is therefore in a better position than other African states to contribute to the financial demands associated with peacekeeping and PCRD on the African continent.

Against this background, the Draft Defence Review 2012 sets down a long-term policy and strategy agenda for the Department of Defence and the SANDF that will set the stage for the next thirty years of defence-related activities. The document suggests that the military will pursue reconstruction and conditions conducive to long-term peace and security building in support of peacekeeping objectives. Practically, this amounts to the provision of critical humanitarian assistance and reconstruction capabilities during the immediate post-conflict phase - operations that will enable and reinforce the process of development and reconstruction. At the same time, the drafters of the Draft Defence Review 2012 make it clear that a purely military approach to peace missions cannot ignore the developmental, economic and governance aspects of peacebuilding as this will effectively impede lasting stability and human security. In this regard, a multidimensional developmental agenda will be pursued by involving the cooperation of military and civilian bodies to accelerate capacity-building and socio-economic development. ${ }^{36}$

Philosophically, this brings us back to a concept which Malan ${ }^{37}$ coined several years ago in relation to South Africa's idea of peacekeeping, namely "renaissance peacekeeping". He pointed out that Nigeria did not seem to be keen to be involved in more than "muscular" peacekeeping (in West Africa), a situation that might still be the case. Equally, he suggested that Egypt was probably less likely to muster the political will or support needed for peacekeeping in sub-Saharan Africa, which might also still be the case. South Africa, he argued, might therefore "be the lead nation of choice, if only by default, and the fact that it was Pretoria that advanced the idea of "renaissance" peacekeeping in the first place". ${ }^{38}$ Currently, Egypt - the second largest African economy - is going through a very challenging 
political transformation process while it might even be argued that Egypt is politically and strategically still too closely associated with the policy projection of the USA. ${ }^{39}$

In view of the above, the following question arises: given the need to steer or even "re-orientate" the SA military to meet the expected future PCRD demands, which implications for defence force design and configuration would be of importance and relevance to the SANDF and should be attended to in the current Defence Review process? Before this is addressed, it is imperative to revisit the tensions around and the main critiques of post-1994 defence thinking.

\section{Defence Thinking since 1994: The Main Critiques}

The South African Defence White Paper and the Defence Review 1998 committed the SANDF to safeguarding the country's sovereignty and territorial integrity. This is the raison d'être for the existence and maintenance of the SANDF. ${ }^{40}$ As already explained, Cabinet's decision on 18 November 1998 to purchase new equipment for the SANDF (specifically for the SA Navy and SA Air Force as the main beneficiaries) was based on the Defence Review 1998. It stipulates that the specific force design required for South Africa should be a high-technology core force, sized for peacetime, but expandable to meet an emerging threat. In the process of policy development, it was eventually concluded that the SANDF should be designed for its "primary object" (protection of the RSA's sovereignty and territorial integrity), and that it has to provide other services of functions through its collateral utility. ${ }^{41}$

However, this paradigm has been contentious and criticised or questioned by several authoritative defence analysts and scholars since 1998. Major General Len le Roux, a former Chief Director: Strategy and Planning in the SANDF, argued that the premise or idea of a South African defence force designed around the "primary function", which is required to execute extensive peace support functions through its collateral utility, is "not valid". ${ }^{42}$ This viewpoint states that defence against external aggression implies certain characteristics in equipment, operations around one's borders, internal lines of communication and the relative proximity of 
support structures, and also that peace missions and related missions, have entirely different requirements. These requirements include:

- protracted deployments over vast distances;

- long-range logistical support;

- air and sea transportability; and

- interoperability with other national forces.

The emphasis in peace missions and related operations therefore shifts from heavy ground mobile forces to light air and sea mobile forces. The nature of peace missions also places specific demands on force design. It requires a force design that utilises a broader spectrum of modern defence functions, which is quantitatively and qualitatively different from the design based on a "primary function" orientation. ${ }^{43}$

In the scholarly domain, Le Roux's sentiments were echoed by (the late) Dr Rocklyn Williams. Williams argued that there was an obsession with the "primary function" in force planning, and that it was wrong to adopt an attitude of "we design for the primary function and we execute the secondary functions with the collateral utility derived from the primary force design". ${ }^{44}$ He argued that the SANDF had neither the budget nor the equipment or the personnel to execute "secondary functions" on the basis of collateral utility. He also maintained that it was primarily in the "secondary functions" arena that most militaries have been deployed in recent times. By the same token, he asserted that the South African military of the future would be increasingly configured around non-traditional roles or "secondary functions".

Another authoritative defence analyst, Dr Jakkie Cilliers, executive director of the Pretoria-based Institute for Security Studies, also constantly asserts that the SANDF's force design was based on "an incorrect interpretation of the primary function", and that this paradigm skewed the SANDF force design. In the words of Cilliers, "I have often argued, and continue to believe that the core orientation of the SANDF should be to serve as 'a force for crisis prevention and crisis intervention', not conventional defence". ${ }^{45}$ This is based on the point that "the requirements for participation in operations under a $\mathrm{UN}$ or $\mathrm{AU}$ mandate remain high, and the expectations upon South Africa massive." The future tasks of the 
SANDF will not involve participation in conflict in the classical sense, but rather involvement in operations of a low intensity and of counterinsurgency in a multilateral environment where South Africa will often serve as a "lead nation". 46

With reference to future defence planning, Mills ${ }^{47}$ points out that the last 66 years since 1946 has seen the longest period over centuries in which no war had broken out between the world's major powers. At the same time, he contends that the threat of conventional wars remains, most notably in Asia. This especially pertains to the risks associated with the resource needs and politico-developmental ambitions of China, Japan and India. Russia, too, may be considered a resurgent power, maintaining a sophisticated defence force and related industry to this end. However, despite all the high-profile spending on aircraft carriers (by China, for instance) and the development of fifth-generation fighters (by Russia in the form of the Sukhoi T-50), if the post-Cold War period is anything to go by, most conflict is likely to manifest in the field of so-called "small" wars. This usually entails conflict at a low intensity level between ill-defined, often non-state opponents, fighting mostly with small arms for complex sets of causes that could range from greed to deeply entrenched grievances.

Several analysts have thus generally argued that the SANDF - under the "primary function" logic - would not only be experiencing a steady erosion of its conventional capabilities, but would reach a point where these capabilities could only be maintained at the expense of its ability to conduct peace missions or related tasks. It has also been argued that the unlikeliness of an external military threat has consistently undermined the credibility of a force design ostensibly motivated by the need for defence against external aggression. Focusing on the "primary function" is therefore not facilitating or enabling the execution of secondary tasks, which are ecisely the tasks that the SANDF is currently performing and will be called upon to perform in the foreseeable future.

In practical terms, it seems that a steady erosion of the SANDF's conventional capabilities has indeed become more of a grim reality. In fact, it seems as if the SANDF's lean budget since the 1990s has already impacted negatively on the retention of highly skilled soldiers in the SA Navy and SA Air Force. To cite one example: in an unprecedentedly frank 
interview, the chief of the SA Air Force, Lieutenant General Carlo Gagiano, raised his concern - even delivered a damning verdict - about the deficiencies in the Air Force's defence capability: ${ }^{48}$

- The budget for the Hawk squadron, used to train pilots to fly Gripen fighter jets is not enough to keep the aircraft airborne for 2000 flying hours a year, i.e. half the optimal flying time.

- The air force cannot afford a permanent maintenance contractor for its aircraft.

- There are delays of more than a year in obtaining spare parts for aircraft.

- There are an insufficient number of trained pilots, instructors and ground crew to ensure a sustainable core of fighter pilots.

- The air force flagship squadron of 26 Swedish Gripen fighters will only be able to fly for a total 250 hours a year, i.e. enough to train one pilot to NATO standards.

In this context, analysts have not only been critical towards issues relating to force design, but have also directed their criticisms towards the ability of the SANDF to respond to crises or other demands placed on the military as a foreign policy instrument in general and a peacekeeping instrument in particular. Helmoed-Römer Heitman, correspondent of Jane's Defence Weekly and probably South Africa's most authoritative defence analyst, argues, "[t]he reality is that the state of readiness (of the SANDF) is appalling: The SANDF is in no way capable of handling anything but the most minor crisis". 99

Another acknowledgement that force-design problems have negatively affected South Africa's role in promoting peace and stability in the region came from the Deputy Minister of Defence, Thabang Makwetla, who admitted that South Africa needs to revise its defence policy and increase its contribution towards peacekeeping on the African continent. He also acknowledged that the distinction between "primary and secondary functions" needs to be reviewed to strike the right balance between these two functions, and to give peacekeeping its rightful place in the SANDF. ${ }^{50}$

In brief, since the end of the 1990s, several defence analysts made it clear that the need to guide force development and force preparation towards 
the optimal support for peace missions in Africa has become imperative. If unaddressed, the SANDF is likely to lose more and more of its status as a professional institution ready to meet the challenges presented to South Africa as a political actor involved in complex regional and international affairs. The SANDF would then be ill-equipped to support the South African government in meeting its future external challenges. This means that, as much as the SANDF is probably still the best-equipped and bestplaced armed force on the African continent to support the AU's Standby Force, ${ }^{51}$ the assumptions on which its current force designs are based hamper the SANDF in its role of facilitating South Africa's foreign policy goals at a global, continental and sub-continental level.

\section{Contemporary Defence Thinking and Considerations}

It seems that the drafters of the Draft Defence Review 2012 have been acutely mindful of criticism that the SANDF's force design was based on what Cilliers has perceived as an "incorrect interpretation of the primary function”, and that such a paradigm skews the SANDF's force design. ${ }^{52}$ One of the most striking examples of the fact that defence thinking has embraced a new paradigm is the following: ${ }^{53}$

[D]efence forces and military personnel will find themselves increasingly employed in essentially non-military roles owing to their readiness profile, training and capacity for organised action ... adaptation to the complexity of future battle space is already well underway, and will require an effective and affordable response. Adversaries will avoid engagements that play to government strengths; for instance, they will seek to deny the defence organisation access to theatre, using all the political and military levers that can be deployed. They will also seek to disperse into an increasingly complex battle space, including amongst the people and below ground, where armed forces will struggle to dominate. The human terrain, and its associated linguistic, ideological, tribal, sectarian and ethnic features, will remain highly complex. These differences will require armed forces to think in a new way about the current Defence Capabilities ...

The authors of the Draft Defence Review 2012 therefore provide for a SANDF which, like modern militaries in general, will be required to play a constructive role in post-war reconstruction efforts in collaboration with other government departments and agencies in addition to its traditional role as a fighting force. In this regard, the challenges of post-conflict 
reconstruction and of establishing a firm foundation for sustainable development will be of particular importance, especially in the areas of SSR and the successful integration of armed forces. ${ }^{54}$

This does not imply a deviation from the principle that the SANDF exists primarily to serve as an instrument of force in preventing others from imposing their will on the South African state by means of force. The drafters of the Draft Defence Review 2012 argue that there is always a real risk that the most carefully considered assessment could suddenly be overturned by unforeseeable events. This could be caused for instance by intervention by an external major power. Furthermore, the 2011 events in North Africa provide a relevant example of unexpected new security threats of an internal nature that could manifest at any given time. The problem is that it is neither possible nor affordable to prepare for every eventuality. The only practical approach to defence planning is to maintain balanced capabilities that will -

- enable the country to meet existing challenges effectively;

- allow the country to deal effectively with foreseeable contingencies;

- be elastic and able to meet developing challenges or threats; and

- provide the foundation on which to build stronger forces when required. ${ }^{55}$

At the same time, the authors of the Draft Defence Review 2012 state that South Africa must be in a position to defend itself autonomously without having to rely on other countries. The Defence Force should therefore be maintained as a "formidable" fighting force that can decisively and successfully defend South Africa's land, air, sea and cyberspaces, vital interests and strategic lines of communication". ${ }^{56}$ The Draft Defence Review 2012 does not express itself on the defence force design or the defence force structure, but explicitly states that a "balanced set of capabilities” must continually be evaluated against the evolving strategic situation and accordingly be refocused, adapted or expanded as situations change or dictate. According to the authors of the Draft Defence Review 2012, a balance must inter alia be maintained in the following key areas. ${ }^{57}$ 
- Between forces for local and expeditionary operations. This means that any country must firstly look to its own defence, but some countries must also, in their own interests, consider regional security and stability. South Africa is such a country and must be in a position to undertake expeditionary operations, be they of a constabulary or peacekeeping nature.

- Between "high tech" and "low tech". "High-tech" military capability can provide a country with an edge over its adversaries or opponents, but "high tech" can be costly and require high maintenance. "Low tech" is in most cases cheaper, but can prove to be a damaging approach if the opposing forces are better equipped. To this end, the choice must be made judiciously on a case-by-case basis.

- Between preparation for "high intensity" and "low intensity" operations. Armies are often accused of planning for "the last war" and not for "the war to come". South Africa is aware of the challenges relating to the factor of unpredictability and uncertainty of future war and conflict, and should therefore be pursuing a balance between high-intensity and low-intensity operations.

- Between defence expenditure and other government expenditure. Under-funded defence forces are disjointed and unable to provide in the needs relating to national security. South Africa will have to find the balance between spending on development and social programmes and national security imperatives.

Any process of defence planning is obviously of great importance, especially given the fact that such a process has important political, economic and social implications for the relevant nation. Moreover, defence planning in a democracy is often an area of serious public contestation and discourse. Considering the above, some South African commentators have argued that South Africa should guard against a situation of underspending on the armed forces, such as that of the British armed forces, ${ }^{58}$ where the British Ministry of Defence is being compelled to save between 10 and 20 per cent of its budget. The main concern here is that Britain could find it difficult to play its required peacekeeping or military roles in future foreign conflicts. 
Furthermore, on the basis of recent western intervention action in Libya, some other commentators seem to feel that African states might face increasing threats by major powers such as the USA, UK or France. This view is premised on the point that western powers tend to spread their influence and control over scarce resources in developing countries under the rubric of "the responsibility to protect" - and such possibilities require (African and South African) military capabilities that could effectively prevent violent regime change. This calls for conventional defence preparation in addition to the need and requirement to assist in peace missions on the continent. ${ }^{59}$

Many other South Africans, however, would argue - on the basis of socio-economic needs in South Africa - that defence spending in South Africa is still too high for a country where acute poverty and desperation is the order of the day for the vast majority of South Africans. Such critiques in recent years came from various role-players in civil society and have, of course, been fuelled by criticism that the country's post-1994 force planning and defence acquisition projects were based on an inappropriate emphasis on "high-tech" military capabilities. Allegations that political elites were benefitting from corrupt defence acquisition packages also did not help to facilitate a sober analysis of South Africa's defence needs and related future financial implications.

My own contention coincides with that of Mills ${ }^{60}$ who argues that the main security challenges or threats in Africa clearly relate to weak states' resource-driven agendas over mineral resources (of which the DRC is an example), energy sources and/or water, or severe stress factors such as burgeoning population numbers and inadequate governance capacity. For such challenges or threats, high-tech weaponry will not provide any solutions because no expenditure on large quantities of weapons or powerful military equipment can adequately or even partly address the causes of such insecurities or their consequences. Mills argues that the security environment facing Africa has less to do with the world of battle tanks and expenditure on conventional military equipment than with community policing and potable water from rain tanks: "[T]he threat to Africa is in weak and failing or failed states, where economies cannot accommodate and provide for the needs, let alone aspirations, of their people" ${ }^{61}$ 
Mills' views seem to be broadly in accordance with those of the composers of the Draft Defence Review 2012. The latter assert and argue comprehensively that future conflicts will be characterised by uncertainty, complexity and an increase in asymmetry. This implies that the future security environment will be characterised by threats and sources of insecurity that emanate from a variety of factors from across the spectrum of conflict. In this context, physical and human complexity will be an important characteristic of the operating environment. The physical environment may pertain to urban areas, but also dense bush, forests, mountains, river systems, swamps and deserts. In such operational conditions, a clear distinction between the different modes of war will become increasingly blurred. This implies that both regular and irregular modes of warfare will be frequently, and almost routinely, integrated. ${ }^{62}$

However, Le Roux ${ }^{63}$ has been highly critical of the Draft Defence Review 2012, arguing that the draft seems to fall back on the previous concepts of the primary function of the SANDF, namely that of defence against external aggression and the need for deterrence based on the country's capabilities. He also takes the view that the primary mission of the SANDF should be reconsidered to bring it more into line with its real task, which is to serve as a policy instrument for conflict prevention, conflict resolution and conflict intervention. As far as Le Roux is concerned, considerations in the Draft Defence Review 2012 are not "brought to their logical conclusion in the definition of the primary mission and required future defence capabilities of the SANDF". ${ }^{64}$

Whether the composers of the Draft Defence Review 2012 should have followed Le Roux's approach, is debatable. I contend that the drafters took due cognisance of major changes and significant developments in the strategic environment of the past two decades, as well as the evolution and development of the AU's peace and security architecture. This is clearly reflected in South Africa's commitment to regional cooperation, conflict prevention, and the commitment of the military instrument to peacekeeping and PCRD. In fact, these considerations have led the drafters to the point where they tried to strike a better balance between high tech and low tech, between preparation for high-intensity and low-intensity operations, and between government expenditure on much-needed socio-economic issues and defence expenditure in the interest of regional security and stability. 
In other words, instead of approaching the primary mission of the SANDF as a way to curb future low-intensity or counter-insurgency types of conflict in a collaborative African security environment, the composers of the Draft Defence Review 2012 opted for a formulation in which the balance of comprehensive defence capabilities was maintained. ${ }^{65}$ If correctly interpreted, this might after all imply that the SANDF will be moving in the direction of what Williams advocated several years ago as the need for cheaper, lighter and less technological-intensive armed forces, but without abdicating the responsibility for preserving South Africa's integrity and sovereignty. It also relates to Williams' argument that South Africa - like Argentina and Brazil in recent years - should move away from the notion that it is a "First World" defence force and that it has the responsibility to develop armed forces that are "more suitable to the real challenges which they face". ${ }^{66}$ Furthermore, the composers of the Draft Defence Review 2012 seemed to have made an honest attempt to steer between those who are challenging defence spending in a context of acute socio-economic needs in South Africa on the one hand, and the approach followed by defence planners who previously configured the South African military (mainly) around conventional military tasks and related "high-tech" equipment on the other.

\section{Conclusion}

When the composers of the Defence Review 1998 drafted a text that outlined the principles for a policy framework of defence in a post-1994 South African democracy, they merely noted South Africa's common destiny with Southern Africa, and that peace and stability could not be achieved under regional instability and poverty. They also stated that it would be in South Africa's long-term security interests to pursue mutually beneficial relations with other Southern African states and to promote reconstruction and development throughout the Southern African region. ${ }^{67}$

In 1999, the South African government reiterated South Africa's central focus on Southern Africa, but also acknowledged the need to respond to calls for participation in (broader) international peace missions. Government further acknowledged the need for capacity building in conflict areas, specifically in the realm of governance. Accordingly, the White Paper on Participation in International Peace Missions stated that, while 
the staging of free and fair elections normally marks the transition to the post-conflict state, there was also a need for effective and efficient governance. This, according to the White Paper, implies the need for adherence to the rule of law, competent and fair judiciaries, effective police services and criminal justice systems, professional civil services and the reorientation of the state towards the pursuance of developmental goals. ${ }^{68}$

The above-mentioned were precisely the challenges that South African role-players, of which the SANDF is a key functionary, encountered in recent years in countries such as Burundi, the DRC and (the former) Sudan. In the DRC, for instance, a critical task of the UN Mission (of which the SANDF has been a major troop contributor) has been that of pursuing peace and stability in the framework of the need for effective state authority in the eastern parts of the country. Autesserre ${ }^{69}$ rightly argues that in the long term, peace in the DRC will be sustainable only if the state in the DRC is stable and its institutions are developed and built up at all levels. What is needed is capacity in public administration, policing, and judicial and correctional services in the DRC - all of which should be developed to a sustainable level to allow especially for the monitoring of human rights. Most importantly, security governance issues, centred on the process of disarmament, demobilisation and reintegration (DDR), have increasingly been recognised as priority peacebuilding tasks in the DRC.

The Draft Defence Review 2012 reinforces the above-mentioned principles and goals, but also articulates the South African commitment to PCRD in a far more specific manner. The provision of critical humanitarian assistance and reconstruction capabilities immediately during the postconflict phase is highlighted as a key performance area. Of further interest is the focus that will be placed on the creation of a firm foundation for sustainable development in the areas of SSR and the successful integration and professionalisation of the armed forces. The latter is a recurring point in the Draft Defence Review 2012. In the final analysis, I therefore contend that the Department of Defence has gained a clearer idea or perspective of what the future role of the South African military should be through the assessment of its function, principles and goals expounded in the Draft Defence Review 2012. 
For the time being, peacekeeping occupies the centre stage of SANDF external operations - with recent peace missions in Burundi, the DRC and Sudan - and will probably continue to do so for the foreseeable future. ${ }^{70}$ In my opinion this implies that the SANDF will have to deal with what Mills describes as "the modern insurgency, which is a profoundly political and developmental task. It is as much about governance as guns, and providing jobs and economic security as military activity”. This is certainly the kind of operational environment and challenges that the SANDF (and other multinational forces) faced in the DRC in the past decade. ${ }^{71}$

Having considered the Draft Defence Review 2012, it could finally be argued that the SANDF will be better geared to deal with its future external role, tasks and challenges: firstly, in terms of having a clearer understanding of the continental and regional security environments; secondly, in terms of understanding the range of contingencies which may arise and the required defence capabilities that are needed to execute the relevant tasks; and thirdly, to pursue a force design that would be aligned with South Africa's political, fiscal and practical interest. I am therefore of the opinion that the new Defence Review, once officially endorsed by parliament and cabinet, will indeed provide the Department of Defence and the SANDF with a more solid base against which long-term plans can be executed and budgets aligned with its strategic, diplomatic and security intent on the continent specifically given the growing demands placed on the SANDF with regard to PCRD on the African continent.

1 At the time of writing it was planned to replace the Defence Review 1998, which was published under the theme of Defence in a democracy, with a new Defence Review 2012, to be published under the theme Defence, security, development.

2 G Mills. "An option of difficulties? A 21st century South African defence review”. Brenthurst Foundation Discussion Paper 7. 2010. 23.

3 Ibid., p. 5.

4 Department of Defence. South African Defence Review 2012. Defence, security, development: Draft document for public engagement as at 12 April 2012. Pretoria: Ministry of Defence and Military Veterans, 2012, 33.

5 At the time of writing, the Draft Defence Review 2012 was still under discussion, but certain 'pointers' have clearly crystallised from what is pursued in terms of strategic thinking on defence issues. The drafting team of the Defence Review 2012 comprised at the outset former National Party politician Roelf Meyer (Chairperson), Premier Thandi Modise (Deputy 
Chairperson), Charles Nqakula, Tony Yengeni, Amb Thenjiwe Mtintso, Dr Pandelane Mathoma, Nonkozo Molai, Col. (Rtd) Granny Seape and Lt. Col. (Rtd) Godfrey Giles. The 'Resource Group' for the Committee comprised Dr Sam Gulube, Rear-Admiral Phillip Schoultz, Dr Moses Khanyile, HelmoedRömer Heitman, Nick Sendall, Brig. Gen. John Gibbs, and Lt. Col. (Rtd) Tefo Keketsi.

Ibid., p. 39.

Ibid., p. 154.

Ibid.

Ibid., p. 43.

R Southall. "Introduction: South Africa, an Africa peacemaker?” In R Southall (ed), South Africa's role in conflict resolution and peacemaking in Africa, Cape Town: HSRC Press, 2006, 1.

A du Plessis. "The military instrument in South African foreign policy". Strategic Review for Southern Africa XXV/2. November 2003. 106, 115.

Department of Defence. "South African Defence Review, as approved by Parliament”. Pretoria: Ministry of Defence, April 1998, 1, 12-19.

A Cottey \& A Foster. "Reshaping defence diplomacy: New roles for military co-operation and assistance". Adelphi Paper 365. 2004. 15.

$\mathrm{C}$ Hill. The changing politics of foreign policy. New York: Palgrave Macmillan, 2003, 82-83.

SHIRBRIG. Introduction to SHIRBRIG. 2012. <http://www.shirbrig.dk/html/sb_intro.htm> Accessed on 2 September 2012.

Du Plessis op. cit., pp. 106, 132.

A Esterhuyse. "Getting the job done: Transformation in the South African Military”. Strategic Review for Southern Africa XXXII/1. 2010. 16-17.

N Nyanda. "The South African National Defence Force and peace missions in Africa”. Paper presented at a conference under the auspices of the African Center for the Constructive Resolution of Disputes (ACCORD), the Centre for International Political Studies (CIPS) and the Pretoria Branch of the South African Institute for International Affairs (SAIIA), University of Pretoria, 27 February 2003, 4.

Ibid., p. 1.

Department of Foreign Affairs. White Paper on South African Participation in International Peace Missions. Approved by Cabinet on 21 October 1998. Tabled in Parliament on 24 February 1999. Cape Town: Parliament, 3. Ibid., p. 19.

Ibid.

R Ferreira \& D Henk. "Military implications of human security: The case of South Africa”. Paper presented at the $45^{\text {th }}$ Anniversary Biennial International Conference of the Inter-University Seminar on Armed Forces and Society, Baltimore, MD, 21 October 2005, 1.

Department of Defence 1998 op. cit., p. 7.

R Gueli, S Liebenberg, E van Huyssteen \& O Maitin. Developmental peace missions theory. Report by the CSIR for the Conflict and Governance Facility (CAGE). Pretoria: CSIR, 2006, 11. 
$<$ http://www.maoner.com/conflict_citation_2005.pdf > Accessed on 5 June 2012.

R Gueli \& S Liebenberg. "The concept of developmental peace missions: Implications for the military and civilians". Conflict Trends 3. 2006. <http://www.accord.org.za/downloads/ct/ct_2006_3.pdf> Accessed on 4 June 2012. Also: R Gueli \& S Liebenberg. "Developmental peace missions: Synergising peacekeeping and peacebuilding in transition periods". In FB Aboagye (ed), Complex emergencies in the 21 $1^{\text {st }}$ century. ISS Monograph 134. May 2007. Pretoria: CSIR. <http://www.iss.co.za/pgcontent.php?UID=17062> Accessed on 4 June 2012.

L Olivier, T Neethling \& B Mokoena. 2009. "Pursuing human security in Africa through developmental peacekeeping: Ambitious construct or feasible ideal?” Supplementa ad Scientia Militaria III. 2009. 172. Gueli et al. op. cit.

J Bertazzo. "Brazilian foreign policy and force projection: Engaging with the Middle East, with eyes on the UN". The Rusi Journal 157/4. August/September 2012. 15. Department of Defence and Military Veterans 2012 op. cit., p. 35.

31 African Union. "Decision on the AU policy framework on post-conflict reconstruction and development". DOC.EX.CL/274(IX). 2006. Available from $<$ http://www.africa-

union.org/root/AU/AUC/Departments/PSC/PCRD/PCRD\%20Main\%20Web\% 20Source/main\%20folder/Decision\%20on\%20Post\%20Conflict.pdf> . 2006. Accessed on 25 May 2012. Also: African Union. "About post-conflict reconstruction and development". 2007. Available from $<$ http://www.africaunion.org/root/AU/AUC/Departments/PSC/PCRD/PCRD\%20Main\%20Web\% 20Source/index.html>. Accessed on 25 May 2012. African Union. AU intensifies its efforts towards post-conflict reconstruction and development. Addis Ababa: African Union Headquarters, 14 September 2011, 1. United Nations Peacebuilding Commission. The Peacebuilding Commission. 2012. <http://www.un.org/en/peacebuilding/> Accessed on 11 September 2012. United Nations. Contributors to United Nations peacekeeping operations. 2012. <http://www.un.org/en/peacekeeping/contributors/2012/apr12_1.pdf> Accessed on 13 June 2012. Quoted by L Engelbrecht. "SA key to effective ASF”. defenceWeb. 18 February 2009. $<$ http://www.defenceweb.co.za/index.php?option=com_content\&view=article \&id=1128\&catid=55:SANDF\&Itemid=108> Accessed on 25 May 2012. Department of Defence and Military Veterans 2012 op. cit., p. 154. M Malan. "Renaissance peacekeeping: A South Africa solution to conflict in the DRC”. ISS Occasional Paper 37. 1999. <http://www.iss.co.za/Pubs/Papers/37/Paper37.html> Accessed on 1 June 2012.

$38 \quad$ Ibid.

39 This point was made by one of the anonymous reviewers of this article. 
40

$42 \quad$ L le Roux. "Defining defence requirements: Force design considerations for

R Williams. 1998. “Against meta-narratives? The strengths and weaknesses of modernism within contemporary defence thinking”. Strategic Review for Southern Africa XX/1. 1998. 23.

L le Roux. "Revision of the South African Defence Review and international trends in force design: Implications for the SA Army”. Paper presented at the SA Army Vision 2010, Seminar 21, 31 October - 1 November 2006, 271. the South African National Defence Force”. African Security Review 8/5. 1999. <http://www.iss.co.za/pubs/asr/8no5/DefiningDefence.html> Accessed on 7 June 2012.

\section{Ibid.}

Williams op. cit., pp. 23-38.

J Cilliers. "The African strategic environment 2020: Challenges for the SA Army”. Paper presented at the SA Army Vision 2010, Seminar 21, 31 October - 1 November 2006, 10.

Ibid., p. 9

Mills op. cit., p. 9.

“Air Force boss slams poor state of affairs”. Sunday Times. 4 April 2010. 4.

As quoted in "SA Military is unravelling". Sunday Tribune. 3 August 2009.

$<$ www.defenceweb.co.za/index.php?option=com_content\&task=view\&id=327 8\&Itemid=321> Accessed on 7 June 2012.

$\mathrm{T}$ Makwetla. "Speech by the Deputy Minister of Defence, Mr Thabang Makwetla, during the Department of Defence Budget Vote, 26 June 2009”. National Assembly, Cape Town, 3.

Engelbrecht op. cit.

Cilliers op. cit., p. 10.

Department of Defence and Military Veterans 2012 op. cit., pp. 166, 173.

Ibid., p. 166.

Ibid., p. 188

Ibid., p. 126.

Ibid., pp. 188-189.

L Scholtz. “Hul weermag ‘ontman’ mor Britte”. Rapport Weekliks. 24 Oktober 2010. xiiI.

This point was made by one of the anonymous reviewers of this article.

Mills op. cit., p. 11 .

Ibid., p. 12.

Department of Defence and Military Veterans 2012 op. cit., p. 166.

L le Roux. "Draft South African Defence Review”. ISS Policy Brief 32. July 2012. 1-3.

Ibid., p. 2.

Department of Defence and Military Veterans 2012 op. cit., p. 126.

Williams op. cit., p. 35.

Department of Defence 1998 op. cit., p. 20.

Department of Defence 1998 op. cit., pp. 3, 19.

S Autesserre. "The trouble with Congo: How local disputes fuel regional conflict”. Foreign Affairs 87/3. May-June 2008. 
<www.foreignaffairs.com/articles/63401/s\%C3\%83\%C2\%A9verineautesserre/the-trouble-with-congo $>$ Accessed on 8 February 2010.

$70 \quad$ Mills op. cit., p. 7.

71 Ibid., p. 13. 